\title{
Archaeological Survey of Property for the Proposed Eagle Pass International Bridge, Maverick County, Texas
}

Daniel R. Potter

Center for Archaeological Research

Follow this and additional works at: https://scholarworks.sfasu.edu/ita

Part of the American Material Culture Commons, Archaeological Anthropology Commons, Environmental Studies Commons, Other American Studies Commons, Other Arts and Humanities Commons, Other History of Art, Architecture, and Archaeology Commons, and the United States History Commons

Tell us how this article helped you.

This Article is brought to you for free and open access by the Center for Regional Heritage Research at SFA ScholarWorks. It has been accepted for inclusion in Index of Texas Archaeology: Open Access Gray Literature from the Lone Star State by an authorized editor of SFA ScholarWorks. For more information, please contact cdsscholarworks@sfasu.edu. 


\section{Archaeological Survey of Property for the Proposed Eagle Pass International Bridge, Maverick County, Texas}

\section{Creative Commons License}

\section{(c) (1) (8)}

This work is licensed under a Creative Commons Attribution-NonCommercial 4.0 International License 


\title{
ARCHAEOLOGICAL SURVEY OF PROPERTY FOR THE PROPOSED EAGLE PASS \\ INTERNATIONAL BRIDGE, MAVERICK COUNTY, TEXAS
}

\author{
Daniel R. Potter
}

Texas Antiquities Committee Permit No. 895

Center for Archaeological Research The University of Texas at San Antonio ${ }^{\circledR}$ Archaeological Survey Report, No. 200 1990 
The following information is provided in accordance with General Rules of Practice and Procedure, Chapter 41.11 (Investigative Reports), Texas Antiquities Committee:

1. Type of investigation: archaeological survey and testing;

2. Project name: New Eagle Pass International Bridge site;

3. County: Maverick;

4. Principal investigator: Jack D. Eaton;

5. Name and location of sponsoring agency: Groves and Associates, San Antonio, Texas, for the City of Eagle Pass, Maverick County;

6. Texas Antiquities Committee Permit No. 895;

7. Published by the Center for Archaeological Research, The University of Texas at San Antonio, San Antonio, Texas 78285-0658, 1990.

A list of publications offered by the Center for Archaeological Research can be obtained by sending $\$ 1.00$ to the Center for Archaeological Research, The University of Texas at San Antonio, San Antonio, Texas 78285-0658. 


\begin{abstract}
In May 1990, archaeologists for the Center of Archaeological Research, The University of Texas at San Antonio conducted a surface survey and subsurface testing program at the site of the proposed Eagle Pass international bridge. The survey was conducted for Groves and Associates, Inc., consulting engineers and project planners, for the City of Eagle Pass. Survey and testing activities were performed in order to locate and evaluate any archaeological remains which might be affected by construction of the bridge and associated facilities. In addition, archival research was conducted at the Eagle Pass library and county courthouse in order to assess potential archaeological resources in the area of the proposed bridge site. The project area has been much disturbed by road, railroad, and water treatment facility constructions. No significant prehistoric or historic archaeological remains were identified during the survey and testing. However further machine and hand excavations within the river terraces to examine for deeply buried cultural deposits and conduct geomorphological recording will be required.
\end{abstract}




\section{TABLE OF CONTENTS}

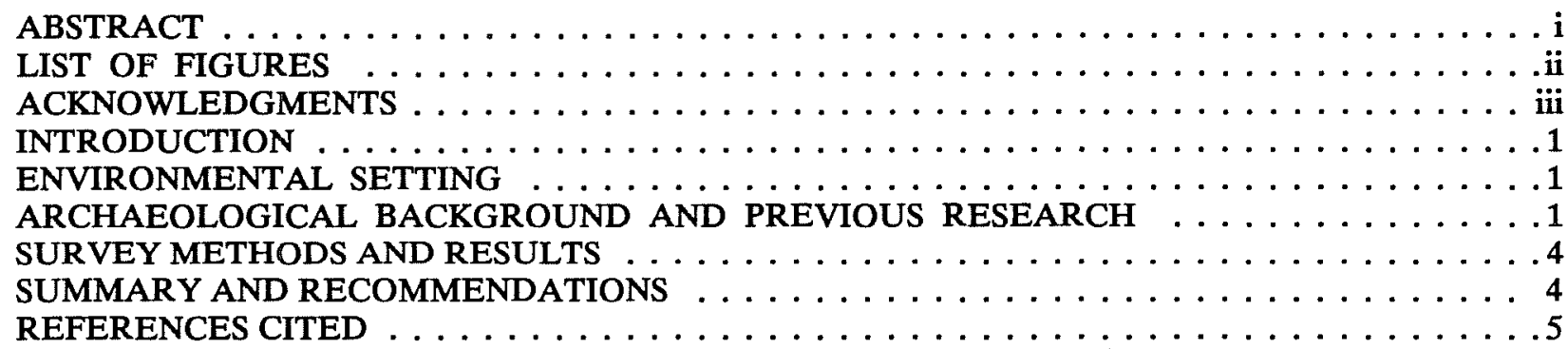

\section{LIST OF FIGURES}

1. Location of the Eagle Pass International Bridge Project Area and Locations of Tests $\ldots \ldots \ldots$

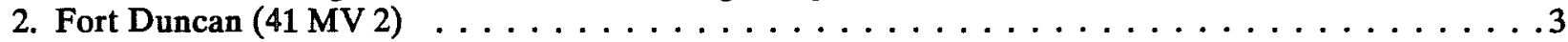




\section{ACKNOWLEDGMENTS}

The author wishes to thank Mr. Alvin L. Groves, P.E., president of Groves and Associates, Inc., for his assistance in completing this project. The company's concern for local historical and archaeological resources is greatly appreciated. Mr. H. Ray Smith served ably as field archaeologist on this project. Both Ray's wife, Candice Smith, and my wife Maureen Brown, volunteered three days of hard, hot work in the field. This project benefited greatly from the effort and expertise of the crew. Grateful thanks also go to Mr. Oscar Rodriguez, Eagle Pass city manager, and Mr. Frank Barrientos of the Fort Duncan Museum for their kind assistance and expertise. John Stockley, a leading expert on border forts in Texas, visited the crew in the field for a brief period, and kindly shared with us his invaluable knowledge of the Eagle Pass area. 


\section{INTRODUCTION}

In February 1990, Mr. Alvin L. Groves of Groves and Associates, Inc., requested that archaeological investigations be carried out by the Center for Archaeological Research (CAR) at The University of Texas at San Antonio (UTSA) in order to evaluate and report any archaeological resources which might be affected by the construction of a bridge between Eagle Pass and Piedras Negras, Mexico, over the Rio Grande. While no obvious historic or prehistoric remains were known to exist within the project area, the proposed bridge site is located within the vicinity of Fort Duncan (41 MV 2), an important but little-known 19th-century military facility. Also, being on the margins of a major river, the Rio Grande, there was a high probability that prehistoric archaeological resources might be present in the project area.

A total of three days of field work was accomplished in May 1990. Field work included a complete surface walkover, supplemented by deep subsurface backhoe tests. Daniel Potter served as project field director, and the work crew consisted of four archaeologists. Jack D. Eaton, acting director of the CAR, supervised this project. The office staff at the CAR were instrumental in the preparation of this report. All recovered materials, field notes, photographs, and other information related to this project are permanently curated at the CAR-UTSA.

The field work was carried out under Texas Antiquities Committee Permit No. 895. Because of international status and federal agency involvement, the overall project is under review by the State Department and the Texas Historical Commission.

\section{ENVIRONMENTAL SETTING}

The project area occupies a west-facing series of low river terraces on the Rio Grande, located on the southern edge of historic Fort Duncan and presentday Eagle Pass, Texas. The area is adjacent to and north of an existing Southern Pacific rail line and bridge between Eagle Pass and Mexico. The project area is bordered on its western edge by the Rio Grande, and rises in a series of eroded terraces to the east (Fig. 1).

Soils in the project area are of the Lagloria-Laredo association. In the lower Rio Grande terraces, are Rio Grande and Zalla soils. The La Gloria very fine sandy loam soils are located in the higher elevation, in the eastern portion of the project area (Stevens and Arriaga 1977). The lower terrace soils (Rio Grande and Zalla) consist of recent deep alluvial sand which is very pale brown in color (Munsell reading on dry sample is $10 \mathrm{YR}$ 7/2-7/3; Munsell Color 1975), and showed no horizon formation in our deep backhoe tests. These immature soils are very susceptible to wind erosion. Lagloria soils are present in the eastern third of the study area, and these are also typical of recent Rio Grande alluvial terraces, commonly being used for irrigation agriculture in Maverick County today (Stevens and Arriaga 1977).

Plant life in the project area includes mesquite, with live oak in the eastern section of the project area and tall grasses and cane being dominant in the lower terraces bordering the Rio Grande. The natural landscape within the proposed bridge site has been extensively changed in recent times. Road building, the construction of a sewage treatment facility, and the Southern Pacific Railroad with its associated buildings and facilities have all served to disturb the natural landscape and possibly any archaeological resources which might have been present within the project area.

\section{ARCHAEOLOGICAL AND HISTORICAL BACKGROUND AND PREVIOUS RESEARCH}

There are no known archaeological sites recorded within the project area. The closest recorded archaeological site to the project area is 41 MK 65, a prehistoric site located several kilometers upstream on an upper terrace of the Rio Grande (Fox and Whitsett 1979). This site consisted of scattered flint debitage and burned sandstone, and was visible eroding out in some places, while in other places being deeply buried perhaps as much as $1.8 \mathrm{~m}$ (Fox and Whitsett 1979).

The project area was possibly within the extreme southern portion of historic Fort Duncan at one time (Fig. 2). The likelihood of finding historic remains from this important but poorly known historic period was of concern during the survey.

Fort Duncan and Eagle Pass have an interesting and important history. The fort, established in 1849 , had an impact on all subsequent developments in this area, on both sides of the Rio Grande. Early on, merchants and traders utilized the relative security of the military road from Fort Duncan north to San Antonio, facilitating border trade. Mexico established its own military post on the opposite side of the Rio Grande, which soon became the nucleus of the Mexican town of Piedras Negras, so named because of the black rocks found on the shore of the Rio Grande there (Osborne et al. 1976). On the Texas side of the river, the 


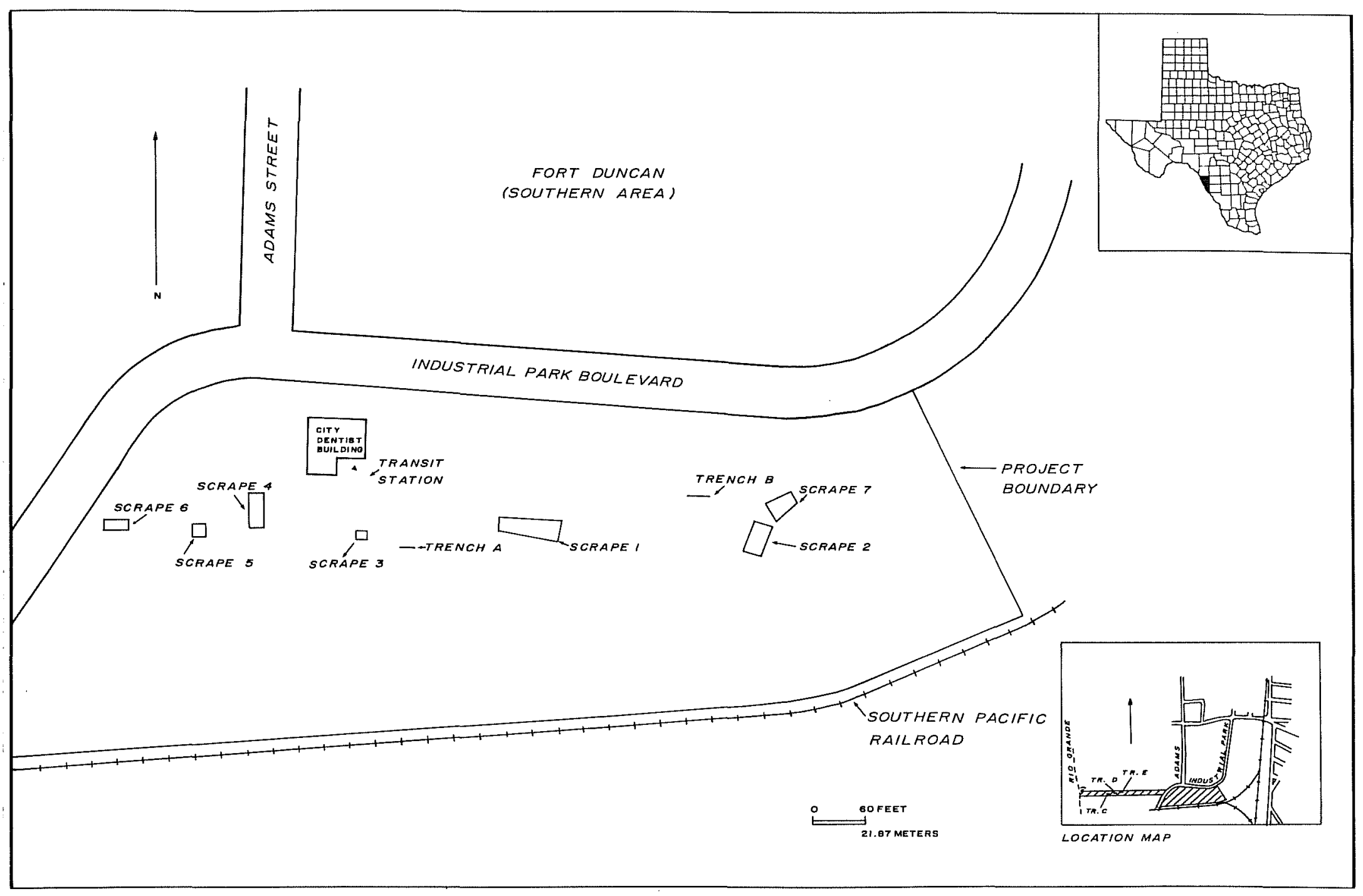

Figure 1. Location of the Eagle Pass International Bridge Project Area and Locations of Tests. 


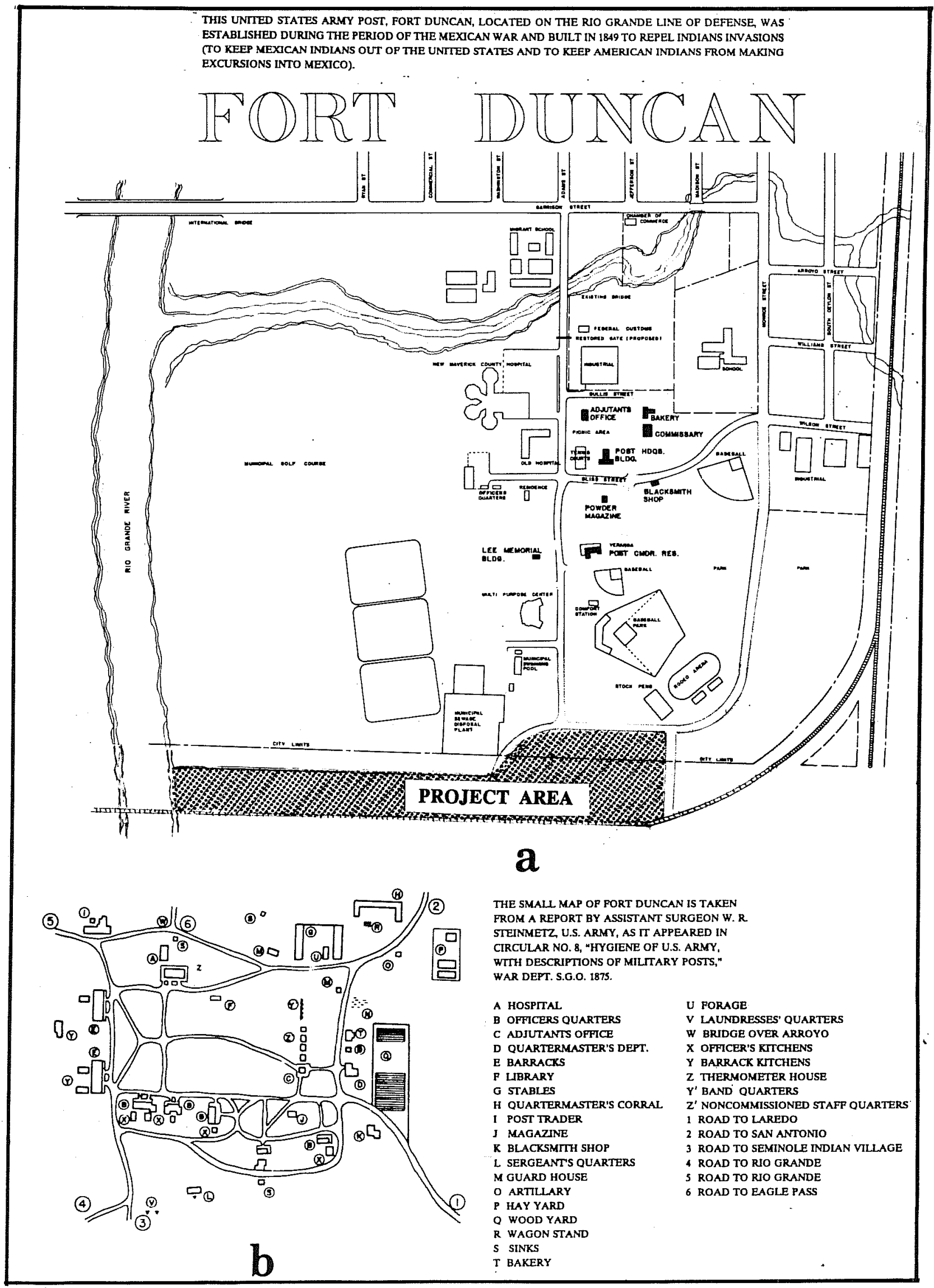

Figure 2. Fort Duncan (41 MV 2). a, current ground plan; b, in 1875. From Osborne et al. (1976). 
presence of Fort Duncan was important in the early history of the town of Eagle Pass and its development at its present location. This was largely because of the California gold rush. In the early 1850 s, immigrants moving west to California would camp north of the fort for protection. This camp slowly developed into a small but permanent settlement, eventually to become the town of Eagle Pass.

Archival research in Eagle Pass by CAR-UTSA personnel revealed that the proposed bridge location is on the southern fringe of Fort Duncan (Fig. 2). Within this general area of the old encampment, but to the north of the survey area, were located ordnance sergeant's quarters, laundresses' quarters, and the road leading from Fort Duncan to the Seminole camp where the Army's Indian scouts lived. A rather informal hand-sketched map of Fort Duncan by Assistant Surgeon W. R. Steinmetz, U.S. Army, done in $\mathbf{1 8 7 5}$ (Steinmetz 1875), shows the location of these structures in the general area. A later, more complete and carefully executed map of Fort Duncan and Eagle Pass made by A. Koch in 1887 also shows a structure which might be the ordnance sergeant's quarters or the laundress quarters. The Koch (1887) map adds the Texas and New Orleans Railroad Company tracks and bridge which had appeared by 1872 (Osborne et al. 1976:30). These appear in about the same location as the present Southern Pacific tracks and bridge adjacent to the project area. This later map (Koch 1887) differs from the earlier Steinmetz (1875) version in that it does not indicate the presence of a road to the Indian scout quarters or the Indian quarters themselves. The precise location of these 62 structures and features cannot be fixed with any certainty on either map.

\section{SURVEY METHODS AND RESULTS}

The present study utilized a $100 \%$ surface examination, supplemented by backhoe trenching in order to detect the presence of any deeply buried subsurface cultural resources (Fig. 1). In addition, backhoe "scrapes," or wide, shallow backhoe excavations, were used to test for the presence of historic materials or features just below the modern disturbed surface. Surficial prehistoric archaeological materials were not found anywhere within the project area. Five deep trenches, which ranged from 1.5 to $3 \mathrm{~m}$ in depth, also failed to encounter any buried cultural remains.

Some historic materials were found on the surface, but only in small quantity, and these were not thought to be in situ artifacts. The only significant historic artifacts found (artifacts that can be associated with the founding and growth of Fort Duncan) were a single .45 caliber center-fire cartridge, two fragments of handmade brick, and a small collection of ceramic fragments recovered during our surface survey. The brick fragments may date from the mid to late 19th century, as they matched the bricks that were observed in the walls of the Fort Duncan blacksmith shop, built prior to 1875 and still standing today. The cartridge, kindly

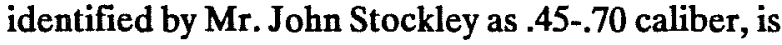
also likely to be associated with Fort Duncan occupation. In 1873, .45 caliber ordnance was adopted by the U.S. Army for all small arms (Gluckman 1965:252), and therefore would have been present at Fort Duncan after this time. The ceramic collection has been evaluated by Maureen Brown, who reports that only one sherd (an isolated find) is of sufficient age to be of interest to this project, a small piece of Guanajuato majolica, a red paste ware with cream-colored glaze, dating from ca. 1810 to 1870 . The cartridge was recovered near the eastern end of our survey transect, in scrape 2, while the brick fragments were found during surface survey in the area of scrape 1. Scrape 1 itself, however, failed to produce any other significant materials. Figure 1 shows the locations of backhoe tests and backhoe scrapes within the project area.

\section{SUMMARY AND RECOMMENDATIONS}

Although the project site is within a potentially sensitive historic and prehistoric area, few archaeological materials were found there. Surface reconnaissance and backhoe trenching failed to produce evidence of any of the structural remains or buried deposits that the literature research had suggested might have been present in the general area of the proposed bridge. It can therefore be assumed that historical structures were not in fact located within the project area as currently defined, or that any structures that were in fact once located here, have been destroyed by later, more recent development of this area. The very thin distribution of historic cultural materials, the apparent disturbance of the site by power machinery, the establishment of a nearby water treatment plant, and the construction of the railroad and road, largely nullifies the value of the project site for future archaeological research and conservation purposes. For this reason, we recommend that no further archaeological research 
is necessary for the project area in connection with bridge development.

We currently do not know exactly where a highway leading to the new bridge will be routed. However, should any buried cultural resources, historical or prehistoric in nature, be uncovered during the planned developments for the international bridge, the Texas Antiquities Committee must be notified and work halted or shifted to another location until an assessment can be made.

\section{REFERENCES CITED}

Fox, D. E. and W. H. Whitsett

1979 An Archaeological Reconnaissance at Eagle Pass, Maverick County. Unpublished manuscript on file at the Center for Archaeological Research, The University of Texas at San Antonio.

Gluckman, Col. Arcadi (Ret.)

1965 Identifying Old U.S. Muskets, Rifles and Carbines. Stackpole Books, Harrisburg, Pennsylvania.

Koch, A.

1887 Bird's Eye View of Eagle Pass, Maverick County, Texas, 1887. Reproduced in Eagle Pass News Guide, by J. F. Woodhull, Centennial Edition, Oct. 21, 1949.

Munsell Color

1975 Munsell Soil Color Charts. Kollmorgen Corporation, Baltimore, Maryland.

Osborne, L., T. Moriarty, S. Spence, and K. P. Almond

1976 Texas Border Architecture Report on the Architectural Survey of Villa Guerrero, Coahuila, Mexico, and Eagle Pass, Texas, United States. School of Architecture, The University of Texas at Austin.

Steinmetz, W. R.

1875 Circular No. 8, Hygiene of the U. S. Army With Descriptions of Military Posts. War Dept. S.G.O. Reproduced in Eagle Pass News Guide, by J. F. Woodhull, Centennial Edition, Oct. 21, 1949.
Stevens, J. W. and D. Arriaga

1977 Soil Survey of Maverick County, Texas. United States Department of Agriculture, Soil Conservation Service, in cooperation with Texas Agricultural Experiment Station. 
